\title{
Fire emission heights in the climate system - Part 1: Global plume height patterns simulated by ECHAM6-HAM2
}

\author{
A. Veira ${ }^{1,2}$, S. Kloster ${ }^{1}$, S. Wilkenskjeld ${ }^{1}$, and S. Remy ${ }^{3,4}$ \\ ${ }^{1}$ Max Planck Institute for Meteorology, Hamburg, Germany \\ ${ }^{2}$ International Max Planck Research School on Earth System Modelling, Hamburg, Germany \\ ${ }^{3}$ European Centre for Medium-range Weather Forecasts, Reading, UK \\ ${ }^{4}$ Laboratoire de Météorologie Dynamique, Paris, France
}

Correspondence to: A. Veira (andreas.veira@mpimet.mpg.de)

Received: 10 December 2014 - Published in Atmos. Chem. Phys. Discuss.: 06 March 2015

Revised: 26 May 2015 - Accepted: 01 June 2015 - Published: 01 July 2015

\begin{abstract}
We use the global circulation model ECHAM6 extended by the aerosol module HAM2 to simulate global patterns in wildfire emission heights. Prescribed plume heights in ECHAM6 are replaced by an implementation of a simple, semi-empirical plume height parametrization. In a first step, the global performance of the plume height parametrization is evaluated for plumes reported in the Multiangle Imaging Spectroradiometer (MISR) Plume Height Project (MPHP) data set. Our results show that the parametrization simulates a largely reasonable global distribution of plume heights. While the modeled global mean plume height $(1411 \pm 646 \mathrm{~m})$ is in good agreement with the observed mean $(1382 \pm 702 \mathrm{~m})$, the upper and lower tails of the plume height distribution tend to be slightly underrepresented. Furthermore, we compare plume heights simulated by the simple parametrization to a more complex, analytical plume model. Major differences in global plume height distributions are found for the lowest $1.5 \mathrm{~km}$, but reasonable agreement is observed for higher plumes. In a second step, fire radiative power (FRP) as reported in the global fire assimilation system (GFAS) is used to simulate plume heights for observed fires globally for the period 2005-2011. The global fraction of simulated daytime plumes injecting emissions into the free troposphere (FT) ranges from $3.7 \pm 0.7$ to $5.2 \pm 1.0 \%$. This range is comparable to results from observational studies, but it is much lower than results for prescribed plume heights in the ECHAM6-HAM2 standard setup. Nevertheless, occasionally deep emission injections exceeding 5-7 km in height are simulated for intense fires and favorable meteorological conditions. The application of a prescribed diurnal cycle in
\end{abstract}

FRP turns out to be of minor importance. For a hypothetical doubling in FRP, moderate changes in plume heights of $100-400 \mathrm{~m}$ are simulated. These small changes indicate that a potential future increase in fire intensity will only slightly impact the emission heights on a global scale.

\section{Introduction}

Vegetation fires, either anthropogenic or ignited naturally by lightning, affect the climate through complex interactions between the biosphere and the atmosphere. Wildfires impact soil, vegetation and ecosystems directly. In addition, aerosols and trace gases emitted into the atmosphere are key parameters of the overall fire climate impact (Bowman et al., 2009; Ward et al., 2012; Keywood et al., 2013). Aerosol particles emitted from fires are known to impact a wide range of atmospheric processes including radiative transfer, atmospheric chemistry and cloud micro-physical processes (Twomey, 1977; Crutzen and Andreae, 1990; Heald et al., 2014). A crucial parameter that has been identified to influence the lifetime of aerosols and thus potentially also their climate impact is the fire emission height, i.e., the altitude above the surface at which fire smoke plumes release emissions into the atmosphere. The terms "fire emission height", "injection height" and "plume height" have been used as equivalent terms in the literature, although they do not always have the same meaning. In this study, we use the term "plume height" to describe the top level above the surface at which emissions are injected, i.e., the "plume-top height". In 
contrast, "emission profiles" specify the entire vertical emission profiles from the surface to the top of the smoke plume.

Theories and models, which describe the process of plume rise, have been developed since the 1970s. Today various semi-empirical (e.g., Briggs, 1975; Achtemeier et al., 2011; Sofiev et al., 2012) and analytical-numerical plume height models (e.g., Heikes and Angeles, 1990; Trentmann et al., 2006; Freitas et al., 2007) are available. In addition to these plume height models which take into account fire properties and atmospheric conditions to calculate plume heights, other parametrizations are solely based on fire brightness temperature (Hodzic et al., 2007) or fire intensity (Lavoué et al., 2000). The review papers of Goodrick et al. (2012) and Heilman et al. (2013) provide extensive summaries of various plume height models. Although a reasonable performance of the plume models has been demonstrated for selected case studies on local or regional scales, the knowledge about smoke plume heights on a global scale is very limited due to a lack of observational data sets. Besides a small number of airborne in situ and ground-based remote-sensing studies, e.g., Melnikov et al. (2008) or Liu et al. (2013), satellite data sets provide observations of potentially global coverage. Although smoke plume measurement uncertainties are only $\pm 200 \mathrm{~m}$ for well-constrained plumes (Kahn et al., 2008; Nelson et al., 2013), only a limited number of plumes are available on the global scale, because a partly manual analysis is required for each individual plume. The most comprehensive data set of individual smoke plume heights is provided by the "Multiangle Imaging Spectroradiometer (MISR) Plume Height Project" (MPHP) that has been analyzed in the framework of several regional studies (Mazzoni et al., 2007; Val Martin et al., 2010; Sessions et al., 2011). These studies indicate a large variability of smoke plume heights all over the globe. Various case studies demonstrated that particularly intense fires can, under favorable meteorological conditions, result in emission injections into the upper troposphere or even the lower stratosphere (Damoah et al., 2006; Luderer et al., 2006; Dirksen et al., 2009). Very rare cases of pyrocumulonimbus events caused by particularly strong fires may even be comparable to small volcanic eruptions (Fromm et al., 2006, 2008; Siddaway and Petelina, 2011). However, the majority of emission injections are limited to the planetary boundary layer (PBL) (Gonzi and Palmer, 2010; Val Martin et al., 2010; Ichoku et al., 2012).

The studies of Hyer et al. (2007), Leung et al. (2007) and Jian and $\mathrm{Fu}$ (2014) showed that the transport of wildfire emissions crucially depends on an appropriate implementation of smoke plume heights that consider the free tropospheric injection of a certain emission fraction. Nevertheless, due to computational costs and the lack of complexity regarding the representation of fire processes in global models, standard versions of state-of-the-art global climate and Earth system models respectively currently make use of simple latitudeand region-dependent vertical emission distributions (Den- tener et al., 2006) or prescribe injections at the surface (e.g., Tosca et al., 2013).

In order to step forward towards a better representation of smoke plume heights in climate models, we implement the simple, semi-empirical plume height parametrization by Sofiev et al. (2012) into the general circulation model ECHAM6. In a first step, we evaluate the performance of the plume height parametrization for selected plumes reported in the MPHP data set. We use fire radiative power (FRP) reported in the MPHP based on MODIS (Moderate Resolution Imaging Spectroradiometer) data to test different versions of the parametrization on the global scale and constrain uncertainties introduced by uncertainties in fire-related and meteorological variables. Furthermore, the Sofiev plume height parametrization is adjusted to the ECHAM6-HAM2 aerosolclimate modeling system by the application of a statisticalempirical tuning. In a second step we simulate plume heights in ECHAM6-HAM2 globally for the years 2005-2011. For these experiments the global fire assimilation system (GFAS; Kaiser et al., 2012) FRP is used as input. We carry out a number of simulations that cover the standard Sofiev parametrization as well as a modified version of the Sofiev parametrization optimized for application in ECHAM6-HAM2. Moreover, effects of the implementation of a prescribed diurnal cycle are investigated. A sensitivity simulation with a global doubling of FRP assesses the implications of a potential climate-induced increase in fire intensity.

The impact of changes in plume heights regarding aerosol burden, transport and radiative forcing is presented in the second part of this two-paper series (Veira et al., 2015).

Section 2 in this paper introduces the ECHAM6 global circulation model extended by the HAM2 aerosol model, configurations of the Sofiev plume height parametrization and the GFAS data set. Section 3 provides a statistical analysis of the global plume height parametrization performance and the application of an statistical-empirical FRP correction. In Sect. 4, we present global plume height patterns simulated by ECHAM6-HAM2 and enhanced by the Sofiev parametrization, and compare these to plume height distributions in the standard version of the ECHAM6-HAM2 model. Furthermore, we discuss the influence of the diurnal cycle in fire intensity. In Sect. 5 we compare plume heights simulated by the Sofiev parametrization to results from a more complex 1-D plume model. The conclusions of this study are summarized in Sect. 6, where we discuss our results in the context of climate and Earth system model development.

\section{Methodology}

In the following, our general setup of the global circulation model ECHAM6, the aerosol model extension HAM2 and the semi-empirical plume height parametrization are described. We introduce the MPHP data set which we use for the evaluation of the plume height parametrization. 
Moreover, the implementation of the GFAS fire intensity data set in ECHAM6-HAM2 is explained. The last two sections present details on the specific model setup used for the plume height evaluation and the simulation of global plume height patterns.

\subsection{ECHАM6-HАM2}

ECHAM6 is a general circulation model and serves as the atmospheric and land component of the Max Planck Institute Earth system model (MPI-ESM). A detailed model description is provided by Giorgetta et al. (2013) and Stevens et al. (2013). For all our simulations we apply a T63 grid (spectral space) which corresponds to a Gaussian grid of approximately $1.875^{\circ} \times 1.875^{\circ}$. In the vertical, we use 47 vertical layers ranging from the surface to $0.01 \mathrm{hPa}$. A computing time step of $10 \mathrm{~min}$ is chosen for all simulations. The plume height parametrization evaluation experiments only apply prescribed sea surface temperature, which originates from the Atmospheric Model Intercomparison Project (AMIP). No nudging against observations is applied for these simulations, because we aim to investigate the basic skills of the ECHAM6-HAM2 model (extended by the plume height parametrization) to capture the spectrum of plume heights, not to reproduce individual plume observations.

For all other simulations, the atmospheric model is additionally nudged against observational data every $6 \mathrm{~h}$. Thus, the model dynamics is forced to stay close to the ERAInterim reanalysis fields (Dee et al., 2011) and changes in global plume height patterns between different plume height parametrizations stay comparable. For these simulations, the ECHAM6 model is extended by the aerosol module HAM2, modeling the dynamics, micro-physics, transport and radiative impact of aerosol species (Stier et al., 2005). The aerosol module represents the aerosol spectrum by superposition of seven lognormal distributions including nucleation, Aitken, accumulation and coarse mode. Vegetation fire emissions, here referred to as "wildfire emissions", are represented by three species: black carbon (BC), organic carbon (OC) and sulfur dioxide $\left(\mathrm{SO}_{2}\right)$. A description of the changes in the HAM model configuration from the original model version HAM1 (Stier et al., 2005) to HAM2, used in this study, has been published by Zhang et al. (2012a). The term "ECHAM6-HAM2" in this paper refers to model version ECHAM6.1.0-HAM2.2.

Plume heights $H_{\mathrm{p}}$ in the standard version of ECHAM6HAM2.2 are generally prescribed as the PBL height plus two model layers:

$H_{\mathrm{p}}=$ PBL Height +2 model layers.

For the large majority of plume heights lower than $4 \mathrm{~km}$, $75 \%$ of the released wildfire emissions are vertically distributed with a constant mass mixing ratio from the surface to the level below the PBL, $17 \%$ are injected into the next model layer above the PBL and $8 \%$ are injected in the layer of height $H_{\mathrm{p}}$. If the PBL height exceeds $4 \mathrm{~km}$, the plume heights are set to PBL height and the emissions are equally distributed with constant mass mixing ratio from the surface to the first model layer below the PBL height. The upper limit of $4 \mathrm{~km}$ is an arbitrary value, but it represents the standard plume height implementation of ECHAM6-HAM2 described by Zhang et al. (2012a). In order to ensure comparability of our results to previous studies, we apply this standard implementation for one reference simulation, whereas improved plume height parametrizations are used for all other simulations.

\subsection{Implementation of an improved plume height parametrization}

To improve the representation of plume heights in ECHAM6HAM2, we implement the simple, semi-empirical plume height parametrization by Sofiev et al. (2012), henceforth named "Sofiev Parametrization" (SP). The original SP predicts plume heights as a function of PBL height, $H_{\mathrm{PBL}}$, Brunt-Väisälä frequency of the free troposphere (FT), $N_{\mathrm{FT}}$, at $2 \times$ PBL height, and the total FRP of a fire, $P_{\mathrm{f}}$ :

$H_{\mathrm{p}}=\alpha H_{\mathrm{PBL}}+\beta\left(\frac{P_{\mathrm{f}}}{P_{\mathrm{f} 0}}\right)^{\gamma} \exp \left(-\delta N_{\mathrm{FT}}^{2} / N_{0}^{2}\right)$.

Here, $\alpha$ is that part of the PBL passed freely, $\beta$ is a scaling factor for the fire intensity, $\gamma$ describes the power-law dependence on $P_{\mathrm{f}}, \delta$ scales the dependence on the stability of the FT, $N_{0}$ is the reference Brunt-Väisälä frequency and $P_{\mathrm{f} 0}$ is the reference FRP. $N_{0}$ and $P_{\mathrm{f} 0}$ are a priori chosen as $N_{0}=\sqrt{2.5 \times 10^{-4}} \mathrm{~s}^{-1}$ and $P_{\mathrm{f} 0}=10^{6} \mathrm{~W}$, respectively. The constants $\alpha, \beta, \gamma$ and $\delta$ have been determined by Sofiev et al. (2012) using a computational learning data set:

$\alpha=0.24, \beta=170 \mathrm{~m}, \gamma=0.35, \delta=0.6$.

As the use of $N_{\mathrm{FT}}$ at $2 \times \mathrm{PBL}$ height is, from a physical point of view, not most appropriate for plumes which do not reach the FT, Sofiev et al. (2012) proposed a two-step iteration scheme, with separate tuning constants for PBL and FT plumes.

For PBL plumes

$\alpha=0.15, \beta=102 \mathrm{~m}, \gamma=0.49, \delta=0.0$,

and for FT plumes

$\alpha=0.93, \beta=298 \mathrm{~m}, \gamma=0.13, \delta=0.7$.

In this study, the performance of the one-step as well as the two-step SP are tested. Konovalov et al. (2014) successfully applied the one-step SP for CO modeling in the CHIMERE model. For stable PBL layers, Kukkonen et al. (2014) achieved improved plume height predictions with the SP when replacing the Brunt-Väisälä frequency of the FT by the inversion layer Brunt-Väisälä frequency. Thus, for 
all nighttime plumes (18:00-08:00 LT) we replace $N_{\mathrm{FT}}$ in Eq. (2) by $N_{\mathrm{PBL}}$ which describes the Brunt-Väisälä frequency of the stable nocturnal boundary layer at the second lowest model layer approximately $150 \mathrm{~m}$ above the surface.

The implementation of this simple plume height parametrization is a significant improvement compared to prescribed plume heights, because it takes into account fire activity as well as ambient meteorological conditions at the time of the fire. However, various parameters, such as fire size and wind drag (Freitas et al., 2007, 2010) or entrainment and multiple core fire structure (Rio et al., 2010), are known to impact plume heights and are not explicitly represented in the SP. On the other hand, studies by Goodrick et al. (2012), Val Martin et al. (2012), Rosário et al. (2013) and Strada et al. (2013) indicate that neither of the more complex plume models shows an outstanding model performance. Moreover, the input parameters required for plume models on the global scale, such as fire size and fire intensity, are still very uncertain (Schroeder et al., 2014). Although FRP is strongly correlated with the heat flux of a fire and thus with fire-induced atmospheric convection, the reliance of plume heights on FRP measured by remote-sensing techniques is much more uncertain than the theoretical relationship between FRP and heat fluxes might suppose. Therefore, the use of a more advanced, more analytical plume model driven by original MODIS or derived FRP data cannot be expected to increase the accuracy of plume height predictions for global climate models with coarse resolution.

\subsection{MPHP satellite data set}

The MPHP represents a synthesis of MISR smoke aerosol data and MODIS MOD14 thermal anomaly data (Nelson et al., 2008, 2013). This unique plume height data set has been accomplished by application of the MISR INteractive eXplorer (MINX) software tool which retrieves windcorrected plume heights from MISR data. In contrast to the plume heights provided in the MPHP, no further processing is applied to the manually selected MODIS MOD14 thermal anomalies which are attributed to individual MISR plumes. The latest release of the MPHP (April 2012) includes data of wildfire smoke plumes in North and South America, Eurasia, Africa and Southeast Asia, observed between 2001 and 2009. The MPHP data set used in this study is based on red band retrievals only as no blue band data were available. For future studies, an explicit validation of red and blue band retrievals is highly desirable, because for thin plumes blue band retrievals are expected to provide more accurate plume height estimations than red band retrievals. Various studies made use of specific parts of this data set: the assignment of plume height distributions to vegetation types in North America (Diner et al., 2008; Val Martin et al., 2010), peat fire plumes in Borneo and Sumatra (Tosca et al., 2011) and the analysis of Australian bush fire plumes (Mims et al., 2010). Each individual plume data set provides extensive informa-
Table 1. FRP bin scheme used for ECHAM6-HAM2 simulations. Individual GFAS fires of $0.1^{\circ} \times 0.1^{\circ}$ resolution are assigned to FRP bins $1-41$ according to their FRP value. See text for more detailed information.

\begin{tabular}{cccccc}
\hline FRP bin no. & $1-10$ & $11-15$ & $16-21$ & $22-26$ & $27-41$ \\
\hline FRP range [MW] & $0-100$ & $100-200$ & $200-500$ & $500-1000$ & $>1000$ \\
Bin width [MW] & 10 & 20 & 50 & 100 & - \\
\hline
\end{tabular}

tion about FRP, optical smoke properties, plume height statistics and wind profiles. For more detailed information, see the official product description at http://www-misr.jpl.nasa. gov/getData/accessData/MisrMinxPlumes/. As stated in the MPHP data quality statement and the error analysis therein, important biases are introduced by pyro-cumulus clouds which hide below-cloud fire activity, by shortcomings in the manual digitization of the plumes and by large uncertainties in the MODIS fire pixels. By excluding plumes of poor or fair retrieval quality (Nelson et al., 2008) and incomplete individual data files, the MPHP provides 6942 plumes which we use for the evaluation of the SP. A visualization of mean annual MPHP plume height values for the year 2006 is presented in Fig. 1. This visualization illustrates the heterogeneous plume height distribution in the MPHP data set and gives a qualitative sense of plume height distributions and FRP diversity. On average, fires of small fire intensity feature lower plume heights, but for presumably favorable meteorological conditions, even low-intensity fires reach plume heights of several kilometers. According to the official MPHP product description and Kahn et al. (2008), an observational plume height accuracy of $\pm 200 \mathrm{~m}$ can be assumed. Due to the fact that MISR detects aerosol plumes that have been aged for a certain period of time, the measured plume heights do not in some cases adequately represent the convection generated by the thermal anomalies at the time of a specific satellite overpass. Thus, MODIS FRP values that correspond to MPHP plume heights can only be seen as a rough approximation.

\subsection{GFAS fire intensity data}

The investigation of global plume height patterns and the subsequent climate impact requires fire intensity data of full global coverage which the MPHP does not provide. In the current standard setup of ECHAM6-HAM2, wildfire emissions from the Aerosol Comparisons between Observations and Models (AEROCOM) project are prescribed (Dentener et al., 2006), but no data on FRP are provided. Therefore, we extended the model to use FRP information from an external data set as a boundary condition. The GFASv1.1 data set (Kaiser et al., 2012) offers not only global FRP data but also corresponding wildfire emissions of $\mathrm{BC}, \mathrm{OC}$ and $\mathrm{SO}_{2}$. Thus, a consistent framework for this study and subsequent investigations of the emission height climate impact is provided. 


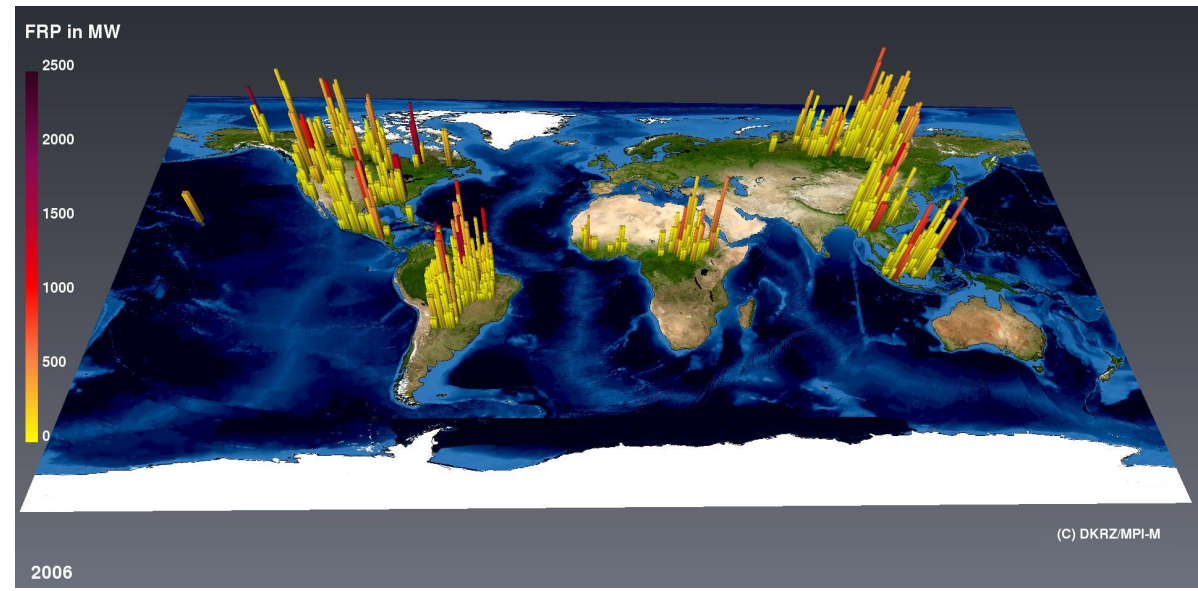

Figure 1. Visualization of gridded mean plume heights of the MPHP data set for the year 2006. The height of each column shows the injection height above the surface. The highest columns represent maximum injection heights of approximately $6 \mathrm{~km}$; we apply a linear scaling of the plume heights. Colors indicate the related total fire radiative power (FRP) detected by MODIS.

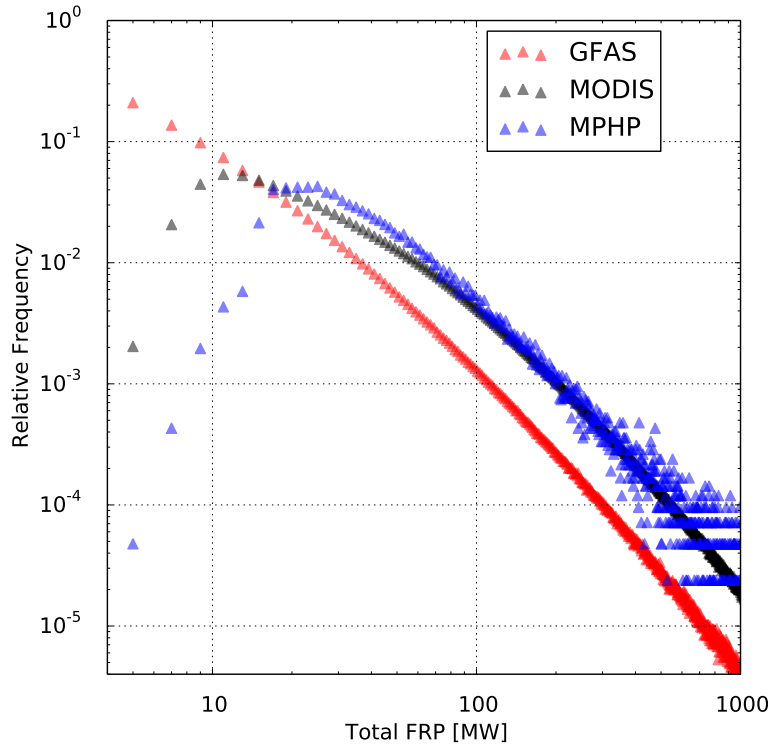

Figure 2. Relative frequency of total FRP per fire for MODIS, MPHP and GFAS data. MODIS refers to total FRP of grouped MOD14 level 2 thermal anomalies which feature distances of $3 \mathrm{~km}$ or less to neighboring fire pixels. GFAS data (version v1.1) are provided as daily mean total FRP of $0.1^{\circ} \times 0.1^{\circ}$ individual grid cells. MPHP data refer to the total FRP of manually selected MODIS daytime fires.

GFASv1.1 applied in this study has a spatial resolution of $0.1^{\circ} \times 0.1^{\circ}$ and a daily temporal resolution. We assume that each $0.1^{\circ} \times 0.1^{\circ}$ grid cell includes only one individual fire if a non-zero FRP value is reported in GFAS.

The $0.1^{\circ} \times 0.1^{\circ}$ grid information of GFAS for the years 2005-2011 is transferred to the ECHAM6-HAM2 T63 grid by combining GFAS FRP values for each individual fire to fixed FRP bins. Table 1 illustrates the used FRP bin scheme. The plume height parametrization is run only once within a grid cell for each FRP bin. With a maximum of 41 FRP bins considered instead of running the plume height parametrization for each individual fire of the GFAS data set at every grid cell, the application of the FRP bin scheme reduces the computational costs for the plume height parametrization calculations by more than $95 \%$. The FRP bins scheme represents a conceptual approach to implement a simplified fire intensity distribution into a global model. The limitation of 41 FRP bins was chosen for technical reasons related to the specific input data format of the ECHAM6 model. The FRP value of bin $1(0-10 \mathrm{MW})$ represents the individual daily mean for the FRP in a particular grid cell, because the variations of the FRP bin 1 values cover several orders of magnitude ( $10^{-6}$ to $\left.9.9 \mathrm{MW}\right)$. For the FRP bins 2 26, a mean FRP value is applied which represents the mean FRP of all fires in this data set for the entire period 20052011. Due to the importance of intense fires with FRP values larger than $1000 \mathrm{MW}$, each of these fires is treated individually and the specific GFAS FRP value is used to calculate the plume height (FRP bins 27-41). For 2 days in the 20052011 period, more than 15 fires with FRP values larger than 1000 MW could be found in one specific grid cell and thus the FRP bins 27-41 are not sufficient. In this case the redundant fires were shifted to neighboring grid cells. Due to the damping factor $\gamma$ in Eq. (2), the small changes in FRP on the order of $0-5 \%$ introduced by application of the FRP bin scheme do not alter plume heights simulated by the SP by more than a few meters. Thus, although the FRP bin scheme represents a simplification of the FRP distribution, the loss of accuracy in global plume height distributions is negligible.

In contrast to the GFASv1.1 data set we apply in this study, Sofiev et al. (2013) used MODIS MOD14 level 2 FRP data 
for the preparation of a plume height climatology. The relative frequency of total FRP per fire for GFAS and MODIS MOD14 level 2 thermal anomalies is presented in Fig. 2 together with the frequency distribution of the MPHP. We group individual MODIS FRP pixels, which have a distance smaller than $3 \mathrm{~km}$ to the next fire pixel, to one fire, because in many cases individual MODIS MOD14 level 2 thermal anomalies are not connected although they belong to the same fire. The method of grouping individual MODIS pixels has successfully been applied by Henderson et al. (2010). The advantage of GFAS over MODIS FRP is the assimilation technique applied in GFAS that produces a considerable fraction of fires which are below the MODIS FRP detection limit and thus not included in the MODIS MOD14 data set. Figure 2 clearly demonstrates the large number of low-intensity fires which is included in GFAS, but not represented in MODIS. MPHP plumes are based on MODIS fire counts, but have been selected manually. Therefore, the FRP frequency distribution of small fires in the MPHP data set is shifted towards more intense fires which are easier to identify by eye. As such the evaluation of the SP using the MPHP data set is of limited significance, because small fires are underrepresented.

\subsection{Model setup for evaluation of the plume height parametrization}

Sofiev et al. (2012) have already shown that their plume height parametrization offers a generally reasonable individual performance, if the parametrization is forced with meteorological input data from ECMWF reanalysis data. Here, we evaluate the SP implemented into the ECHAM6 general circulation model. For long-term climate simulations, the individual plume height performance is less important than the statistical performance of the global plume height distribution. Therefore, we do not force the ECHAM6 model with reanalysis data, but apply free model runs with prescribed sea surface temperature. Moreover, we quantify FRP uncertainties in more detail than previously done by Sofiev et al. (2012). The SP is run offline based on the meteorological parameters from the ECHAM6 output and FRP from the MPHP data set as described in Sect. 2.3. We run ECHAM6 simulations with prescribed AMIP-II sea surface temperature for 2000-2010 to generate a climatology of meteorological input parameters required in the SP. As we expect only a minor impact of aerosol emissions on the meteorological parameters which determine the plume height and as GFASv1.1 data are only available for 2005-2011, we do not use the HAM2 aerosol module for the SP evaluation experiments. In total, the SP is run for a selection of 6942 MPHP plumes. To take into account the FRP uncertainties of $30 \%$ in the MPHP data set, we run the SP additionally for fire intensity values of $0.7 \times$ FRP and $1.3 \times$ FRP. For each plume we test the standard SP (EVAL-SOFIEV-1) as well as the two-step iteration scheme (EVAL-SOFIEV-2) described in Sect. 2.2. The SP is run at the particular day when the plume was reported in the MPHP. To estimate plume heights in favorable meteorological conditions, we additionally simulate the plume heights at each day of the month and analyze the upper $25 \%$ of all plumes within a month. This simulation is called EVALSOFIEV-1-METEO. A summary of all simulations for the evaluation of the SP is provided in Table 2.

Sofiev et al. (2012) found a tendency of the SP to underestimate particularly high plumes, although the plume height spectrum was not subject to a more detailed analysis. There might be various factors which contribute to an underestimation of high plumes including low fire emissivity at $4 \mu \mathrm{m}$ and an underestimation of FRP due to the smoke opacity effect. Investigations by Schroeder et al. (2014) who compared MODIS FRP data to the Autonomous Modular SensorWildfire (AMS) airborne multi-spectral imaging system indicate that MODIS underestimates the FRP of high-intensity fires. For a particular fire of approximately $500 \mathrm{MW}$, the underestimation of surface FRP was found to be nearly $50 \%$. For a smaller fire of $72 \mathrm{MW}$ (detected by AMS), the surface FRP bias was roughly $20 \%$. There is a general tendency of MODIS to underestimate FRP for high plumes due to the smoke which decreases the detectability of the thermal anomalies below the smoke. This opacity effect of smoke plumes has been described by Kahn et al. (2008). As we use direct MODIS FRP for our plume height simulations, we expect similar underestimations of FRP in our plume height calculations.

Peterson and Wang (2013) and Peterson et al. (2014) investigated MODIS FRP data and found sub-pixel information to be useful for the prediction of high-altitude injections. However, so far there is no global data set available that provides this sub-pixel data for a wide range of fire sizes and intensities. Even though the magnitude of the underestimation cannot be quantified on the global scale, satellite pictures of the MPHP data set clearly indicate that the underestimation of MODIS FRP tends to increase with plume height. This holds especially for calm conditions and pyrocumulus events as one can see for a number of plumes in the MPHP data set (personal communication with David Nelson). To take into account this significant FRP underestimation of particularly strong fires, we apply an empirical FRP correction of the SP which tunes deep plumes higher than a threshold $H_{\text {deep }}$ towards the observations by replacing the FRP $P_{\mathrm{f}}$ in Eq. (2) with $P_{\mathrm{f}}^{*}$, where

$$
P_{\mathrm{f}}^{*}=P_{\mathrm{f}} \times\left(\frac{H_{\mathrm{p}}}{H_{\text {deep }}}\right)^{\varepsilon} .
$$

We empirically vary $\varepsilon$ and define $H_{\text {deep }}$ based on the statistical performance of EVAL-SOFIEV-1 evaluated with the MPHP data set. The empirically determined best performance values of $\varepsilon$ are subsequently used for the simulation EVAL-SOFIEV-MODIFIED (see Table 2). 
Table 2. Setup of simulations for evaluation of various implementations of the Sofiev plume height parametrization. Each version of the parametrization is additionally run with FRP values of $\pm 30 \%$ to estimate the impact of FRP uncertainties on the plume heights. See text for a detailed description of the individual simulation setups.

\begin{tabular}{cccc}
\hline Simulation name & Plume height parametrization & Meteorology & FRP from MPHP \\
\hline EVAL-SOFIEV-1 & Sofiev one-step & day of observation & original \\
EVAL-SOFIEV-2 & Sofiev two-step & day of observation & original \\
EVAL-SOFIEV-1-METEO & Sofiev one-step & $25 \%$ most favorable conditions & original \\
EVAL-SOFIEV-MODIFIED & Sofiev one-step + FRP correction & day of observation & tuning for plumes $>H_{\text {deep }}$ \\
\hline
\end{tabular}

Table 3. Setup of global plume height pattern simulations. All simulations are nudged towards observations every $6 \mathrm{~h}$; simulation period is 2005-2011.

\begin{tabular}{cccc}
\hline Simulation name & Plume height parametrization & Diurnal cycle of FRP & Emission distribution \\
\hline HAM2.2-STANDARD & PBL +2 model layers & NO & 25\% into FT, 75\% into PBL \\
SOFIEV-ORIGINAL & SOFIEV (original) & NO & constant mass mixing ratio \\
SOFIEV-DCYCLE & SOFIEV (original) & YES & constant mass mixing ratio \\
SOFIEV-2X-FRP & SOFIEV (original, 2xFRP) & NO & const. mass mixing ratio \\
SOFIEV-MODIFIED & SOFIEV (modified) & YES & constant mass mixing ratio \\
\hline
\end{tabular}

\subsection{Model setup for simulation of global plume height patterns}

We run the ECHAM6-HAM2 general circulation model as described in Sect. 2.1 in nudged mode (ERA-INTERIM data) for the years 2004-2011 to simulate global plume height patterns. Due to the limited availability of GFASv1.1 (years 2005-2011) plume heights for 2004 are driven by 2008 GFAS fire intensity data. The year 2004 serves thereby solely as model spin-up and is excluded from our analysis. In total we run five ECHAM6-HAM2 simulations: one reference simulation "HAM2.2-STANDARD", for which we use the standard plume height distribution scheme and four simulations which represent different configurations of the SP (Table 3). Simulation SOFIEV-ORIGINAL is based on the original SP as described in Sofiev et al. (2012) and evaluated in simulation EVAL-SOFIEV-1. In SOFIEV-DCYCLE, we apply a simplified diurnal cycle according to Zhang et al. (2012b), which distributes $80 \%$ of the FRP constantly during daytime (08:00-18:00 LT) and the remaining $20 \%$ during nighttime (18:00-08:00 LT). In simulation SOFIEV-MODIFIED, we use the results from the plume height parametrization evaluation to tune the SP. Vertical emission distributions in experiment HAM2.2-STANDARD are implemented as described in Sect. 2.1, while all SOFIEV simulations apply a constant mass mixing ratio from the surface to the top of the plume.

Simulation SOFIEV-2X-FRP is a sensitivity scenario of more intense fires in a warmer climate and serves as a sensitivity test. A climate-change-induced increase in fire activity has been found based on climate projections for the end of the 21st century particularly for boreal regions, (e.g., Stocks et al., 1998; Kloster et al., 2012; de Groot et al., 2013). Since no global estimates of a future intensification in FRP are available, we only consider a hypothetical global doubling in fire intensity in simulation SOFIEV-2X-FRP.

\section{Plume height parametrization performance}

This chapter presents the evaluation of the various versions of the SP described in Sect. 2.5. Table 4 provides statistical values of the global plume height distribution for all versions of the SP and the observational MPHP data set. Parametrization EVAL-SOFIEV-1 shows basic agreement with the observed spectrum for a wide range of plume heights. The global mean plume height of EVAL-SOFIEV-1 $(1389 \pm 572 \mathrm{~m})$ is very close to the observed global mean of $1382 \pm 702 \mathrm{~m}$. However, there is a general tendency of the SP to overestimate low plumes and to underestimate high plumes. Similar problems to reproduce particularly high as well as low plumes have been reported for other plume rise parametrizations by Val Martin et al. (2012).

The uncertainties in plume heights introduced by the $\pm 30 \%$ uncertainty in the FRP impact the mean plume heights by less than $100 \mathrm{~m}$. The two-step SP (EVALSOFIEV-2) provides a slightly better representation of the plume height variations, but the one-step SP holds a smaller positive model bias for low plumes and a better representation of extraordinarily high plumes. For favorable meteorological conditions (parametrization EVAL-SOFIEV1-METEO), the increase in plume heights compared to EVAL-SOFIEV-1 ranges between 200 and $400 \mathrm{~m}$ except for the highest plumes which significantly exceed this range ( $1250 \mathrm{~m}$ for the maximum plume height). Compared to the FRP uncertainty, the meteorological parameters turn out to 
Table 4. Statistical analysis of different versions of the Sofiev plume height parametrization implemented in ECHAM6. The KS tests describe results for a Kolmogorov-Smirnov test, the square root error is shown as cumulative sum over the cumulative probability function. Uncertainties of mean heights indicate 1 SD (Standard Deviation).

\begin{tabular}{|c|c|c|c|c|c|}
\hline Data set & MPHP OBS & EVAL-SOFIEV-1 & EVAL-SOFIEV-2 & EVAL-SOFIEV-1-METEO & EVAL-SOFIEV-MODIFIED \\
\hline Mean plume height $[\mathrm{m}]$ & $1382 \pm 702$ & $1389 \pm 572$ & $1517 \pm 637$ & $1651 \pm 599$ & $1411 \pm 646$ \\
\hline Mean plume height FRP $+30 \%[\mathrm{~m}]$ & - & $1478 \pm 616$ & $1603 \pm 668$ & $1750 \pm 649$ & $1511 \pm 717$ \\
\hline Mean plume height FRP $-30 \%[\mathrm{~m}]$ & - & $1279 \pm 519$ & $1403 \pm 596$ & $1554 \pm 616$ & $1292 \pm 567$ \\
\hline 10th percentile $[\mathrm{m}]$ & 651 & 789 & 834 & 1011 & 789 \\
\hline 25 th percentile $[\mathrm{m}]$ & 892 & 988 & 1048 & 1231 & 988 \\
\hline 50th percentile $[\mathrm{m}]$ & 1248 & 1280 & 1402 & 1544 & 1280 \\
\hline 75th percentile $[\mathrm{m}]$ & 1713 & 1666 & 1834 & 1937 & 1688 \\
\hline 90th percentile $[\mathrm{m}]$ & 2271 & 2123 & 2282 & 2421 & 2218 \\
\hline 95th percentile $[\mathrm{m}]$ & 2671 & 2465 & 2675 & 2782 & 2621 \\
\hline 99th percentile [m] & 3709 & 3193 & 3629 & 3576 & 3556 \\
\hline Max plume height $[\mathrm{m}]$ & 11986 & 6153 & 5620 & 7404 & 7786 \\
\hline Mean top 10 plumes [m] & $6122 \pm 2008$ & $5153 \pm 596$ & $5129 \pm 308$ & $5521 \pm 908$ & $6235 \pm 881$ \\
\hline $\mathrm{KS}$ test $d$ value & - & 0.081 & 0.117 & - & 0.081 \\
\hline KS test $d$ value upper $40 \%$ & - & 0.075 & 0.249 & - & 0.034 \\
\hline Cumulative square root error & - & 0.161 & 0.300 & - & 0.034 \\
\hline
\end{tabular}

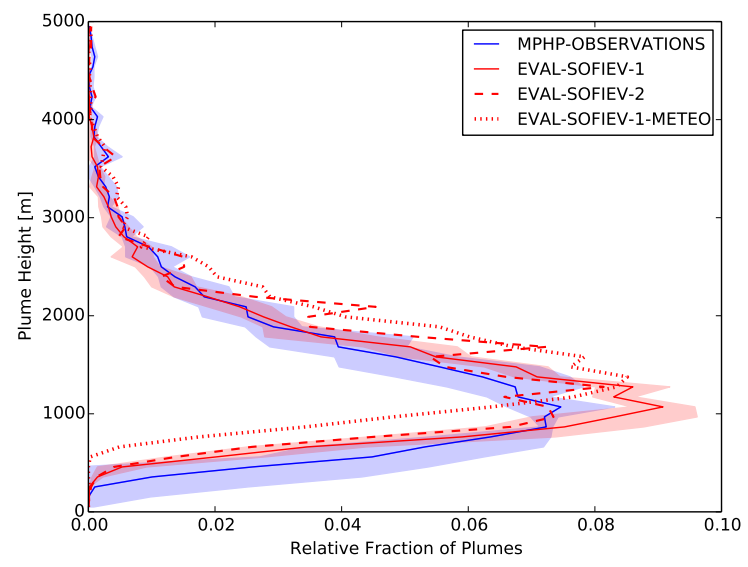

Figure 3. Global mean plume height distribution for different plume height parametrizations and MPHP observations. Blue shading represents uncertainties of $\pm 200 \mathrm{~m}$ in the plume height observations, red shading represents a $\pm 30 \%$ FRP uncertainty applied for the plume height parametrizations.

be more important for plume heights on the global scale. Due to the simplified representation of plume buoyancy in the Sofiev formula, the interpretation of these findings has to be taken with care, but the setup of our simulations does not allow for a more detailed analysis. A Kolmogorov-Smirnov test (KS test) indicates that the best statistical performance is provided by EVAL-SOFIEV-1, for both, the complete distribution, as well as the uppermost 40 percentiles. The uppermost 40 percentiles serve best for the KS test, because for these percentiles the cumulative probability distribution of EVAL-SOFIEV-1 continuously exceeds the MPHP distribution.

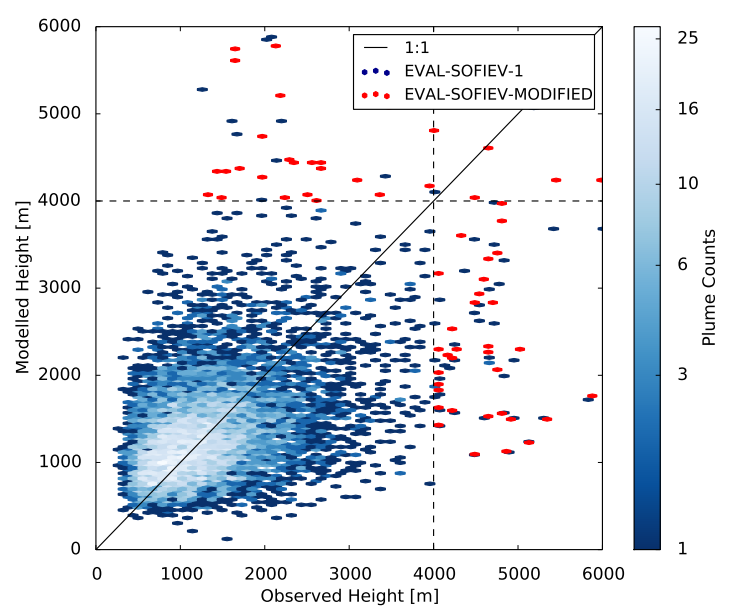

Figure 4. Performance of the one-step Sofiev plume height parametrization (EVAL-SOFIEV-1) for plumes below $6 \mathrm{~km}$. Honeycomb colors indicate the number of plumes in a specific $100 \mathrm{~m}$ height bin for EVAL-SOFIEV-1. Red honeycombs represent plumes for EVAL-SOFIEV-MODIFIED. For reasons of clarity, only EVALSOFIEV-MODIFIED plumes above $4 \mathrm{~km}$ are shown.

Figure 3 visualizes the vertical plume height distribution for the different versions of the SP. While the EVALSOFIEV-1-METEO parametrization lies significantly above the observations for the entire plume height range below $4 \mathrm{~km}$, EVAL-SOFIEV-1 matches the uncertainty range of the observations for a large part of the plume height spectrum. The spikes in the EVAL-SOFIEV-2 distribution originate from the two-step algorithm which tends to shift plumes away from levels of the PBL height.

As particularly high plumes are in many cases linked to large emission injections, these plumes require special 


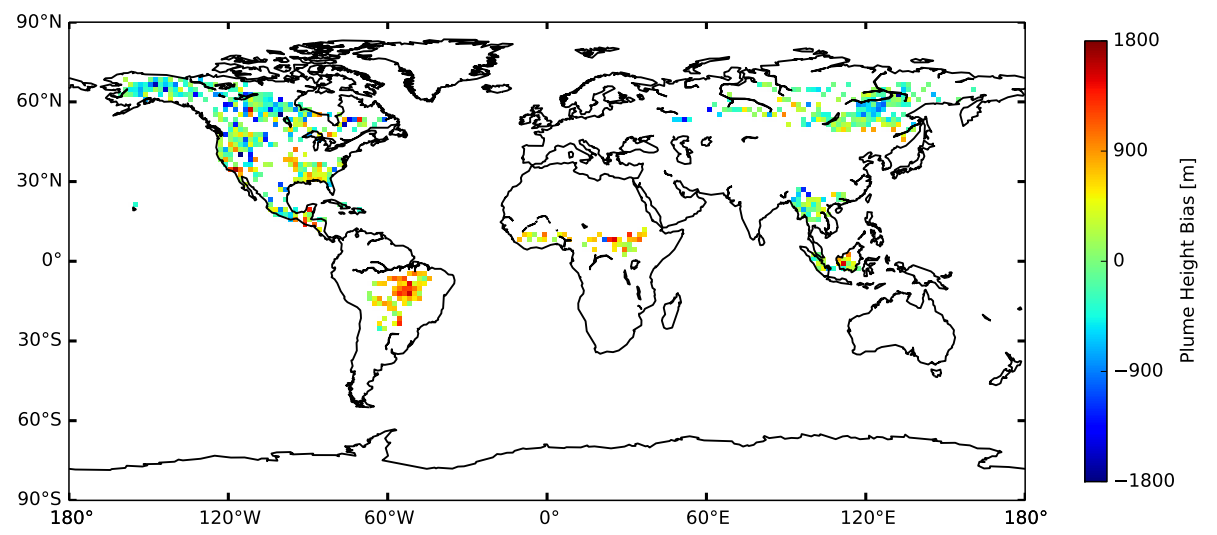

Figure 5. Mean plume height bias of simulation EVAL-SOFIEV-1 for 2001-2009 compared to the observational MPHP data set (EVALSOFIEV-1 minus MPHP). Blue colors indicate underestimation of plume heights by the model, red colors indicate overestimation of plume heights by the model. The large majority of grid boxes contain more than one individual plume; in these cases averaged biases are shown. The large areas of white colors, e.g., in Europe and Australia, represent the limited global coverage of the MPHP data set as no plumes are available in these regions.

attention in the context of global climate modeling. Based on empirical variations of the tuning parameters in parametrization EVAL-SOFIEV-MODIFIED (see Eq. 6), we found the best statistical performance for $\varepsilon=0.5$ and $H_{\text {deep }}=$ $1500 \mathrm{~m}$. The correction of FRP for deep plumes significantly improves the overall plume height parametrization performance on the global scale (see Table 4). The cumulative square error of the entire distribution is decreased from 0.16 for parametrization EVAL-SOFIEV-1 to 0.03 for parametrization EVAL-SOFIEV-MODIFIED. While the mean plume height of EVAL-SOFIEV-MODIFIED (1411 \pm $646 \mathrm{~m}$ ) does not change substantially compared to EVALSOFIEV-1 $(1389 \pm 572 \mathrm{~m})$, the maximum plume heights are increased from 6.1 to $7.8 \mathrm{~km}$ and the $\mathrm{KS}$ test $d$ value for the uppermost 40 percentiles is reduced by $\approx 50 \%$. Figure 4 shows the frequency of plume heights in specific $100 \mathrm{~m}$ bins for parametrization EVAL-SOFIEV-1 (0-6 km) and EVALSOFIEV-MODIFIED (4-6 km only). The large majority of low plumes are adequately represented by EVAL-SOFIEV1 , but for high plumes $>4 \mathrm{~km}$, the FRP correction applied in EVAL-SOFIEV-MODIFIED is particularly important. While the number of plume heights $>4 \mathrm{~km}$ is 38 in the observational MPHP data set (out of 6942 plumes in total), the number of plumes $>4 \mathrm{~km}$ is increased from 12 in simulation EVAL-SOFIEV-1 to 33 in simulation EVAL-SOFIEVMODIFIED (see Fig. 4).

Figure 5 presents a global map of the mean plume height bias simulated by EVAL-SOFIEV-1 compared to MPHP observations for all analyzed plumes. Very similar patterns apply for parametrization EVAL-SOFIEV-MODIFIED as the FRP correction introduced in EVAL-SOFIEV-MODIFIED only marginally effects the mean plume heights. Although significant individual over- and underestimations on the grid box scale are observable, there is no clear region-specific bias pattern observable in the extratropics. In tropical South
America, plumes generally tend to be slightly overestimated, but in other parts of the tropics (e.g., Southeast Asia) tropical plumes are captured very well by the SP. A more detailed analysis shows that the positive model bias in tropical South America is primarily related to plumes with heights smaller than $3 \mathrm{~km}$. Due to the vast majority of these tropical low plumes injecting emissions into the well-mixed PBL, this bias is generally of limited importance for the emission height climate impact.

\section{Global plume height patterns}

In the next sections, global plume height patterns simulated by the various plume height implementations in ECHAM6HAM2 are presented. All simulations are based on FRP data as reported by the GFASv1.1 data set. We analyze global and regional differences in plume heights, impacts of a diurnal and seasonal cycle and the fraction of free tropospheric injections.

\subsection{Global patterns of mean and maximum plume heights}

Table 5 shows a comparison of global plume height statistics for all five simulations introduced in Sect. 2.6. We apply a linear weighting of plume heights with FRP. The weighting becomes particularly important for global mean plume height values as the large number of small fires in GFASv1.1 dominates the plume height spectrum. Thus, intense fires injecting large amounts of emissions are more adequately represented in global plume height statistics.

The ECHAM6-HAM2 standard plume height implementation (PBL height +2 model layers) results in a mean global plume height of $2798 \pm 813 \mathrm{~m}$. This plume height value is considerably higher than all mean plume heights in 
Table 5. Plume height characteristics for various plume height implementations. All values represent global means for 2005-2011. Uncertainties for mean top 100 plumes represent 1 SD. A description of the simulation setups is provided in Table 3.

\begin{tabular}{|c|c|c|c|c|c|}
\hline Simulation Name & HAM2.2-STANDARD & SOFIEV-ORIGINAL & SOFIEV-DCYCLE & SOFIEV-MODIFIED & SOFIEV-2X-FRP \\
\hline mean height $[\mathrm{m}]$ & $2798 \pm 813$ & $1327 \pm 457$ & $1526 \pm 517$ & $1559 \pm 577$ & $1500 \pm 549$ \\
\hline 10th percentile $[\mathrm{m}]$ & 1784 & 833 & 956 & 956 & 924 \\
\hline 25 th percentile $[\mathrm{m}]$ & 2173 & 1012 & 1164 & 1164 & 1128 \\
\hline 50th percentile $[\mathrm{m}]$ & 2733 & 1256 & 1449 & 1459 & 1406 \\
\hline 75th percentile $[\mathrm{m}]$ & 3364 & 1552 & 1790 & 1827 & 1754 \\
\hline 90th percentile $[\mathrm{m}]$ & 3883 & 1892 & 2167 & 2255 & 2169 \\
\hline 95th percentile [m] & 4199 & 2161 & 2461 & 2607 & 2511 \\
\hline 99th percentile $[\mathrm{m}]$ & 4798 & 2831 & 3195 & 3543 & 3356 \\
\hline max height $[\mathrm{m}]$ & 14408 & 6386 & 7121 & 8701 & 7788 \\
\hline Mean top 100 plumes [m] & $9510 \pm 1027$ & $4786 \pm 389$ & $5676 \pm 477$ & $6782 \pm 632$ & $5755 \pm 485$ \\
\hline
\end{tabular}

the various versions of the SP, which range from $1327 \pm$ $457 \mathrm{~m}$ (SOFIEV-ORIGINAL) to $1559 \pm 577 \mathrm{~m}$ (SOFIEVMODIFIED). The introduction of a diurnal cycle in FRP (SOFIEV-DCYCLE), as well as the additional ECHAM6HAM2.2-specific FRP correction for high plumes, does not impact mean plume heights by more than $450 \mathrm{~m}$ except for the 99th percentile. For a doubling in FRP (simulation SOFIEV-2X-FRP), mean plume heights range between the SOFIEV-ORIGINAL simulation and the SOFIEV-DCYCLE simulation. Daytime plumes in SOFIEV-DCYCLE and SOFIEV-MODIFIED are weighted approximately 6 times greater than nighttime plumes due to their higher FRP values. However, although the differences between the various versions of the SP are very limited for $99 \%$ of all plumes, the disproportionately important $1 \%$ of the highest plumes show larger differences.

Figure 6 presents maximum values of hourly plume heights for all simulations from 2005 to 2011. On average, plume heights simulated by the SP show significantly smaller maximum plume heights than the plume heights simulated by HAM2.2-STANDARD. By taking into account not only the PBL height but also the fire intensity, the SP represents a more heterogeneous pattern of plume heights (see Fig. 6a-d). The HAM2.2-STANDARD plume heights follow a distinct gradient from the Equator to the poles due to their dependence on PBL height. In contrast to the HAM2.2STANDARD scenario, SP maximum plume heights are generally lower than $4 \mathrm{~km}$ in many regions. Plume heights greater than $4 \mathrm{~km}$ are simulated in the subtropical and tropical savannah, in remote mid-latitudes and in boreal regions. The differences in plume heights between the various versions of the SP (Fig. 6b-d) are much smaller than the differences to HAM2.2-STANDARD (Fig. 6a). The implementation of a diurnal cycle (SOFIEV-DCYCLE, Fig. 6c) introduces a significant mean plume height increase in regions of high fire intensity. For SOFIEV-MODIFIED, the FRP correction for plumes $>1500 \mathrm{~m}$ leads to a further increase in plume heights. In contrast to the SOFIEV-ORIGINAL simulation, for SOFIEV-MODIFIED a very small fraction of individual plumes reaches plume heights of more than $7 \mathrm{~km}$.
In parts of Australia, boreal Canada and Siberia, some high plumes simulated by SOFIEV-MODIFIED rise substantially above the HAM2.2-STANDARD plume heights.

Sofiev et al. (2013) presented zonal mean injection profiles and regional maximum plume heights of $5.5 \mathrm{~km}$ with the majority of plumes injecting into the lowest $1000 \mathrm{~m}$. In contrast to our study, the results by Sofiev et al. (2013) were based on MODIS MOD14 FRP data and were therefore lacking a significant fraction of small fires which is included in GFASv1.1. However, the dominance of emission injections into the lowest $1-2 \mathrm{~km}$ is observable in both studies. The tuning of high plumes applied in SOFIEV-MODIFIED leads to a small fraction of plume heights above 6-7 km which is not included in Sofiev et al. (2013), although such high plumes are reported in the MPHP data set. In the MPHP data set, one single, particularly high plume even exceeds a plume height of $10 \mathrm{~km}$ and lies thus beyond the spectrum of our SP simulations.

Gonzi et al. (2015) applied a modified version of the 1-D plume rise model by Freitas et al. (2007) for global modeling of plume heights for the year 2006 and analyzed regional plume height distributions in Indonesia, North America, Africa and Siberia. The authors found a very limited number of plumes (approximately 10-100 plumes for 2006) which exceeded injection heights by more than $5 \mathrm{~km}$ above the PBL height. Due to differences in model resolution, FRP inventories and temporal resolution, the study by Gonzi et al. (2015) is not directly comparable to our simulations. Nevertheless, the magnitude of the highest plumes shows basic agreement with simulation SOFIEV-MODIFIED.

\subsection{Vertical emission distributions}

For all SP simulations we assume a vertical emission distribution of constant mass mixing ratio in all levels below the top plume height. In the HAM2.2-STANDARD simulation a fixed fraction of the emissions $(25 \%)$ is injected in the next two layers above the PBL (see Sects. 2.1 and 2.6). Figure 7 illustrates the vertical emission distributions of all simulations as 7 year global means. All versions of the SP are 

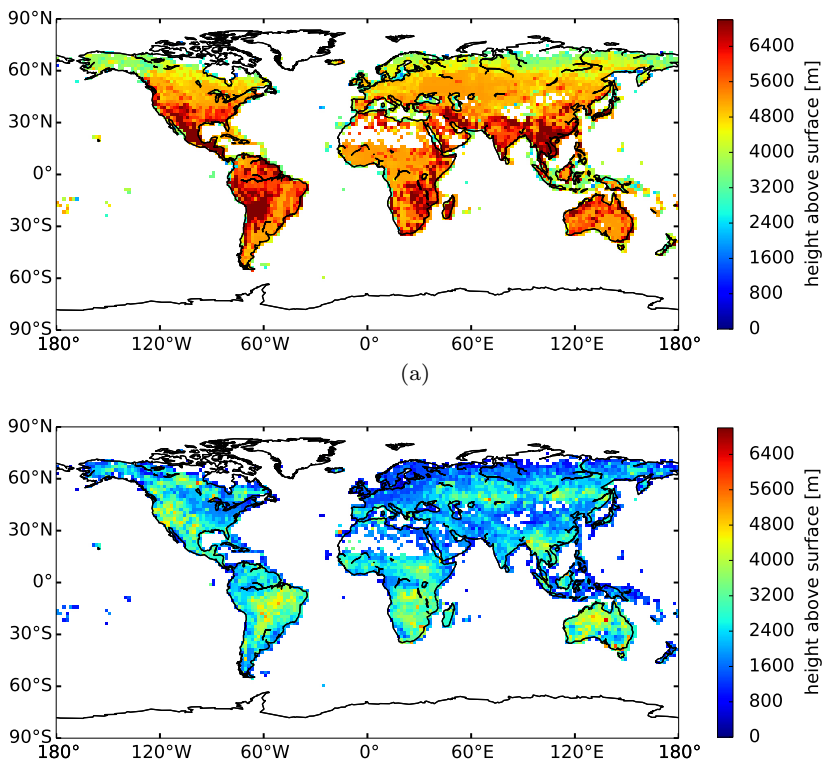

(b)

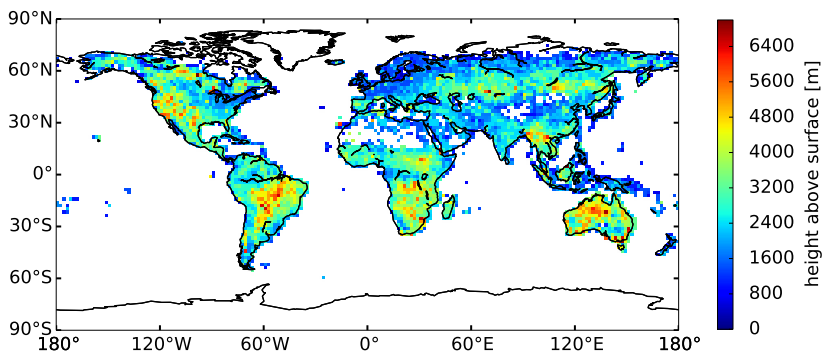

(c)

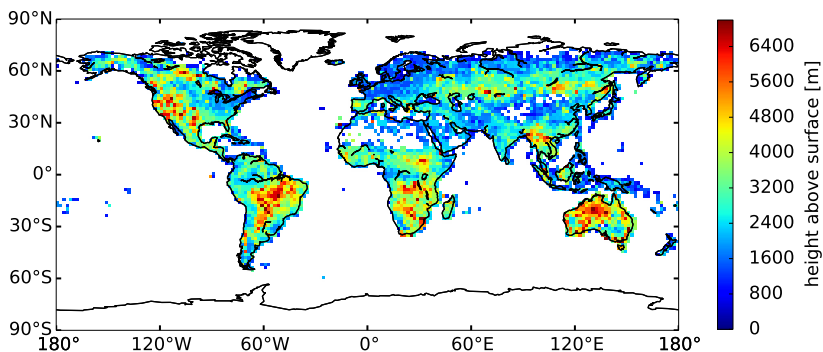

(d)

Figure 6. Maximum plume heights for simulations HAM2.2STANDARD (a), SOFIEV-ORIGINAL (b), SOFIEV-DCYCLE (c) and SOFIEV-MODIFIED (d). Plume heights for (a) represent standard plume heights in ECHAM6-HAM2.2, plume heights in (b) to (d) are based on various versions of the Sofiev plume height parametrization. For a detailed description, see Sect. 2.6.

emitting the major fraction of the emissions below $800 \mathrm{hPa}$ with small differences between these simulations. For simulation HAM2.2-STANDARD, a considerably larger emission fraction is injected into layers $3-5 \mathrm{~km}$ above the surface.

The SP simulations are basically in line with the observational study of Jian and Fu (2014) who found on average only $45 \%$ of smoke MISR pixels above $1 \mathrm{~km}$. Kipling et al. (2013) showed that, for prescribed standard emission pro-

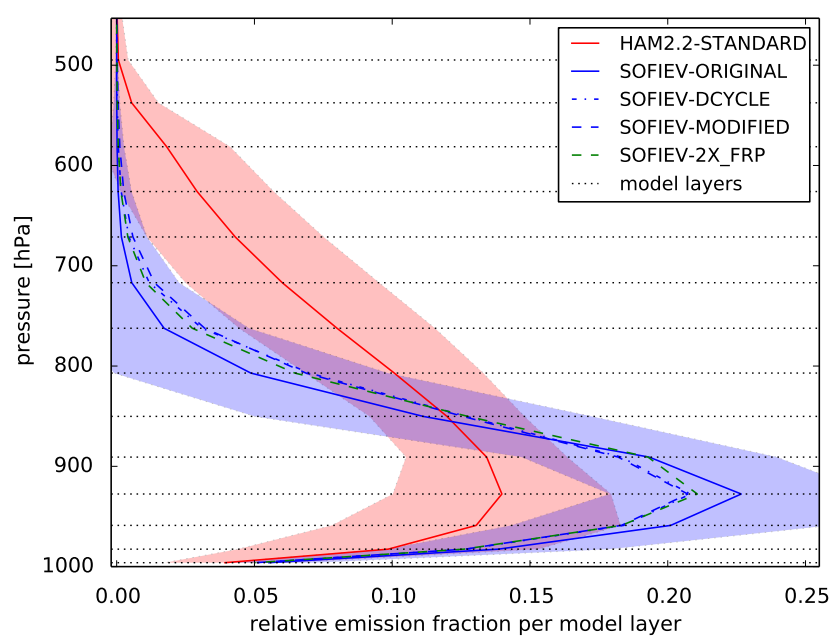

Figure 7. Globally averaged vertical emission distribution of wildfire emissions for different emission height parametrizations 20052011. All emission distributions are weighted with FRP, i.e., strong fires contribute disproportionately high to the distribution (see text Sect. 4.1). Red and blue shadings indicate $1 \mathrm{SD}$ of simulation HAM2.2-STANDARD and SOFIEV-ORIGINAL, respectively. Note that the SOFIEV-DCYCLE and SOFIEV-MODIFIED lines largely overlie for pressure levels $>700 \mathrm{hPa}$. For a detailed description of the simulation setups (see Table 3 ).

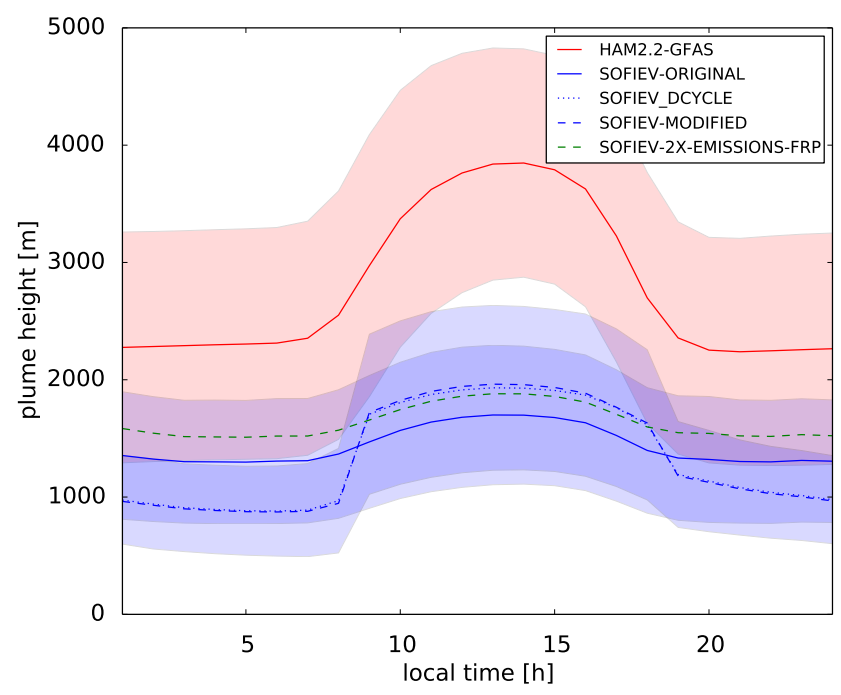

Figure 8. Global mean diurnal cycle of plume heights for different plume height implementations. Shadings indicate 1 SD.

files, ECHAM6-HAM2 generally overestimates BC in the upper troposphere over the Pacific. This model bias might to some extent be related to too high plumes in ECHAM6HAM2 standard. A doubling of FRP is not found to considerably change the vertical emission distributions compared to simulation SOFIEV-ORIGINAL. 


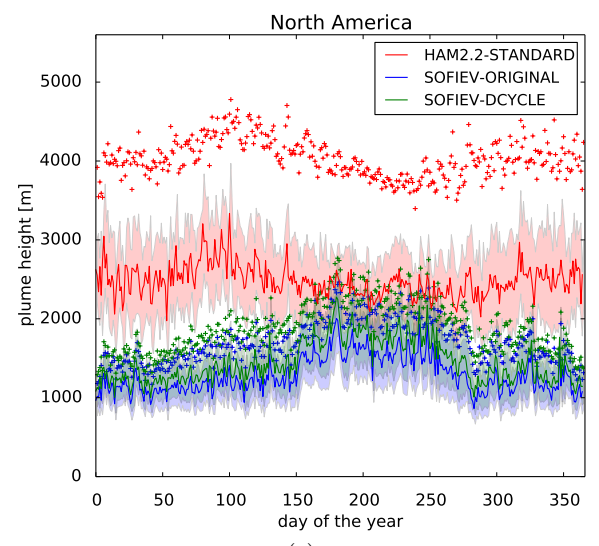

(a)

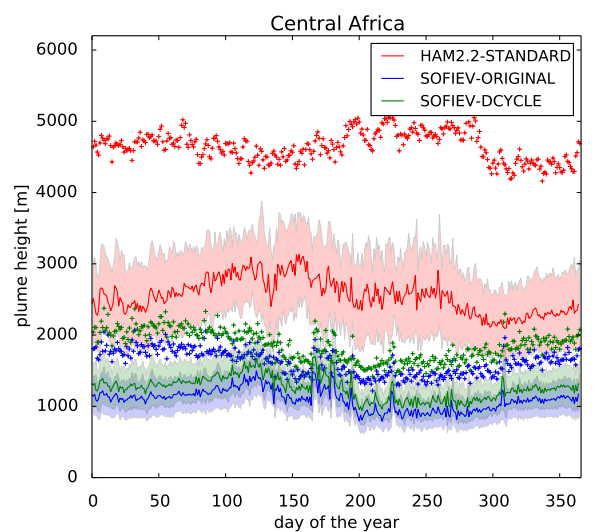

(b)

Figure 9. Seasonal cycle of daily mean plume heights for North America (a) and Central Africa (b). Shading represents 1 SD; crosses indicate maximum individual mean daily values in these regions. See text and Table 3 for a more detailed description of model simulations HAM2.2-STANDARD, SOFIEV-ORIGINAL and SOFIEV-DCYCLE.

\subsection{Diurnal and seasonal cycles}

The purely PBL-related plume height variations in HAM2.2STANDARD result in a distinct diurnal cycle of plume heights (see Fig. 8). The SP, which also takes into account the FRP and Brunt-Väisälä frequency, shows a less pronounced diurnal cycle. Overall, simplified diurnal variations in FRP (simulation SOFIEV-DCYCLE) turn out to impact the overall diurnal cycle by $200-500 \mathrm{~m}$ and are therefore of similar importance as diurnal variations in PBL and Brunt-Väisälä frequency. The limited impact of a diurnal cycle in FRP in all SOFIEV simulations coincides with the results from Gonzi et al. (2015) who showed that the differences in CO profiles are only marginally influenced except for the lowest $1-2 \mathrm{~km}$ when diurnal FRP variations are accounted for.

For analysis of the simulated seasonal cycle in plume heights, we choose North America $\left(30-60^{\circ} \mathrm{N}, 90-120^{\circ} \mathrm{W}\right)$ as a region with a distinct fire activity peak during the northern hemispheric summer and tropical Africa $\left(0-15^{\circ} \mathrm{N}\right.$, $\left.15^{\circ} \mathrm{W}-45^{\circ} \mathrm{E}\right)$ as a region of maximum fire activity in southern hemispheric summer conditions. Figure 9 shows seasonal variations of the HAM2.2-STANDARD, SOFIEVORIGINAL and SOFIEV-DCYCLE simulations. In both regions, seasonal variations of area averaged plume heights are not very pronounced, since a large number of small fires dominates the mean plume heights. There is a distinct seasonal cycle in the top plume heights observable in the SOFIEV simulations for North America and - though less pronounced - also for Africa. This seasonal cycle in plume heights is mainly related to the seasonal cycle in individual FRP values peaking in the summer season. For HAM2.2STANDARD, the seasonal cycle is not represented because PBL heights do not show distinct seasonal patterns in those regions.

\subsection{Fraction of free tropospheric injections}

In HAM2.2-STANDARD, all plumes are prescribed to reach or exceed PBL height. In all versions of the SP, the fraction of plumes that reach the FT is significantly smaller than $100 \%$ (see Table 6). The simulated global fraction of FT plumes ranges between $9.7 \pm 1.4$ and $15.0 \pm 2.0 \%$. For daytime plumes, which emit $80 \%$ of the total wildfire emissions, the fraction of FT plumes is substantially smaller (3.7$5.5 \%)$.

A similar fraction of $4 \%$ daytime plumes reaching the FT was presented by Tosca et al. (2011) for Indonesia. For North America Val Martin et al. (2010) found a fraction of 4-12\%. In contrast, Diner et al. (2008) and Mims et al. (2010) found values of $26 \%$ for North America, and $30 \%$ for Australia, respectively. A slightly smaller fraction of North American FT injections (14-22\%) has also been identified by Gonzi et al. (2015).

\section{Comparison to other plume height parametrizations}

The SP represents a simple, semi-empirical plume height parametrization that takes into account fire intensity as well as meteorological parameters for calculation of plume heights. This parametrization does not explicitly account for fire size, wind drag, entrainment and the number of updraft cores which have been shown to influence plume heights (Freitas et al., 2007, 2010; Liu et al., 2010; Rio et al., 2010). But for long-term climate modeling, the computational costs for the implementation of more complex analytical models are disproportionate to the benefits. Nevertheless we compare the plume heights calculated by the SP to the widely used 1-D plume height model by Freitas et al. (2007) for a limited period of time. We use fire and meteorological data from the Monitoring Atmospheric Composition and 
Table 6. Global fraction of FT plumes for all day (00:00-24:00), daytime (08:00-18:00) and nighttime (18:00-08:00) plume heights. Uncertainties indicate SDs of day to day variations.

\begin{tabular}{cccc}
\hline Simulation name & FT Fraction 00:00-24:00 [\%] & FT Fraction 08:00-18:00 [\%] & FT Fraction 18:00-08:00 [\%] \\
\hline SOFIEV-ORIGINAL & $11.9 \pm 1.7$ & $3.7 \pm 0.7$ & $17.8 \pm 2.3$ \\
SOFIEV-DCYCLE & $9.7 \pm 1.4$ & $5.2 \pm 0.9$ & $12.8 \pm 1.7$ \\
SOFIEV-2X-FRP & $15.0 \pm 2.0$ & $5.5 \pm 1.0$ & $21.6 \pm 2.7$ \\
SOFIEV-MODIFIED & $9.7 \pm 1.4$ & $5.2 \pm 1.0$ & $12.8 \pm 1.7$ \\
\hline
\end{tabular}

Climate (MACC-II) project for the period 1 January 2014 to 13 July 2014. The MACC-II data were most suitable for this comparison, because a modified version of the Freitas plume rise model (PRM-MODEL; Freitas et al., 2007; Gonzi et al., 2015) had already been implemented in MACC-II. Therefore, the required additional effort for the implementation of the SP was very limited. As the PRM-MODEL requires the fire size of each fire which is not provided in GFASv1.1, it was unfortunately not possible to run the PRM-MODEL simulations for our ECHAM6-HAM2.2 experiment setups.

The PRM-MODEL provides entire detrainment profiles, but for comparability to the SP we only analyze the mean height of maximum injections. In the PRM-MODEL, maximum injection heights are defined as the average of the levels for which the detrainment is $>50 \%$ of the maximum detrainment. Moreover, the PRM-MODEL output is assimilated to fill observational gaps as described by Kaiser et al. (2012). The implementation of the PRM model for all individual fires entailed roughly a doubling in computation time for the MACC-II system, whereas the additional computational costs of the SP implementation are negligible. A comparison of global mean daily plume height distributions of the PRM model vs. SP implemented in the MACC-II system is shown in Fig. 10. For this period, the PRM model provides a mean plume height of $1287 \pm 807 \mathrm{~m}$, for SP the mean is $1392 \pm 506 \mathrm{~m}$; the 10th percentile in PRM is only $273 \mathrm{~m}$, whereas it is $809 \mathrm{~m}$ in SP; the 95th percentile is $2663 \mathrm{~m}$ in PRM and $2322 \mathrm{~m}$ in SP; the mean plume height of the highest 100 plumes in the PRM is $7251 \pm 466 \mathrm{~m}$, for the SP it is $4406 \pm 329 \mathrm{~m}$. Overall the differences between the models are largely restricted to the lowest $500-1000 \mathrm{~m}$ within the wellmixed PBL and furthermore to the upper 97-99 percentile. However, a modified SP in MACC to improve occasionally high plumes (which would require additional tuning similar to our FRP correction in simulation SOFIEV-MODIFIED) would shift the plume height distribution to a better agreement with the PRM (see Table 5).

\section{Summary and conclusions}

In this study prescribed plume heights in ECHAM6-HAM2.2 have been replaced by the implementation of different versions of a simple, semi-empirical plume height parametrization after Sofiev et al. (2012). In a first step we evaluated

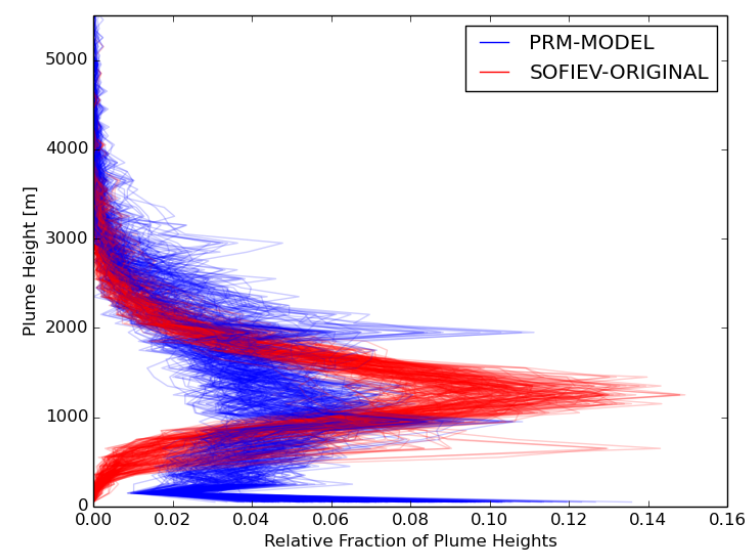

Figure 10. Plume height distributions calculated by the PRMMODEL and the original version of the SP (SOFIEV-ORIGINAL) implemented in MACC-II for 1 January 2014 to 13 July 2014. Each line represents the global mean plume height distribution of a particular day.

the modeled plume height distribution against 6942 plumes of the Multiangle Imaging Spectroradiometer (MISR) Plume Height Project (MPHP) data set. Overall the semi-empirical parametrization shows a reasonable performance within the uncertainty range, although low plumes tend to be slightly overestimated and high plumes tend to be underestimated. A statistical-empirical correction for the fire radiative power (FRP) of high plumes turned out to significantly improve the uppermost $10 \%$ of the plume height spectrum, because this correction compensates the smoke opacity effects which reduce the detectability of FRP for intense fires. For the plume height parametrization used in this study, meteorological conditions impact the plume heights more effectively than uncertainties in FRP. The reliance of plume heights on FRP in the Sofiev parametrization represents a very simplified approach which provides reasonable statistics on the global scale, but it might fail for the prediction of individual plumes.

In a second step we simulated plume heights for fire activity of global coverage for 2005-2011 using FRP reported in the global fire inventory GFASv1.1 (Kaiser et al., 2012) as input for the plume height parametrization. The application 
of the fire-intensity-dependent plume height parametrization introduced considerable changes to global plume height patterns compared to the ECHAM6-HAM2 standard plume height implementation which solely depends on PBL height. The global mean plume height simulated by the modified Sofiev plume height parametrization is $1559 \pm 577 \mathrm{~m}$ with a fraction of $3.7 \pm 0.7 \%$ of daytime plumes emitting into the FT. The highest 100 plumes reach altitudes of $6.1-8.7 \mathrm{~km}$ above the surface. On the global scale, plume heights simulated by the Sofiev plume height parametrization are significantly lower than for ECHAM6-HAM2 prescribed plume heights and show a much more heterogeneous spatial distribution. As a results of the strong damping in the FRP impact on plume heights described by the Sofiev plume height parametrization, a hypothetical doubling in future fire intensity, as well as the implementation of a diurnal cycle in FRP, only marginally increases the vast majority of emission heights. Basic global plume height patterns are rarely affected by these changes in FRP, but for the uppermost 10 percent of all plumes, an average increase in plume heights by $300-500 \mathrm{~m}$ is simulated.

The lack of high-resolution plume height data sets of full global coverage remains a limiting factor for the evaluation of plume height parametrizations in climate and Earth system models. Nevertheless, the implementation of an advanced plume height representation into a climate model is an essential step forward to advance the progress in our understanding of the overall fire emission climate impact. The simulations presented in this study form the basis for the investigation of the fire emission height impact on black carbon long-range transport and radiation which we show in the second part of this two-paper series. For subsequent studies without observational FRP data, we will couple the implemented plume height parametrization to a mechanistic interactive fire model (Lasslop et al., 2014) within a global vegetation model. This will enable the investigation of climate-change-induced past and future changes in fire intensity and related changes in plume heights.

Acknowledgements. We are grateful to the DFG for funding the Emmy-Noether junior research group "Fire in the Earth System". We also thank Johannes Kaiser and Angelika Heil (ECMWF, Reading, UK) for providing the GFAS data set and Felicia Brisc (University of Hamburg, Germany) for graphical support of the MPHP visualization. Special thanks goes to Ronan Paugam (Kings College, London) who developed the PRM MODEL code which we implemented into the MACC-II system. Furthermore, we acknowledge the helpful comments and suggestions from David Nelson (NASA Jet Propulsion Laboratory) on the MPHP data set and the critical internal review by Stephan Bakan (MPI-M, Hamburg).

The article processing charges for this open-access publication were covered by the Max Planck Society.

Edited by: K. Tsigaridis

\section{References}

Achtemeier, G. L., Goodrick, S. A., Liu, Y., Garcia-Menendez, F., $\mathrm{Hu}, \mathrm{Y}$. , and Odman, M. T.: Modeling smoke plumerise and dispersion from southern United States prescribed burns with daysmoke, Atmosphere, 2, 358-388, doi:10.3390/atmos2030358, 2011.

Bowman, D. M. J. S., Balch, J. K., Artaxo, P., Bond, W. J., Carlson, J. M., Cochrane, M. A., D'Antonio, C. M., Defries, R. S., Doyle, J. C., Harrison, S. P., Johnston, F. H., Keeley, J. E., Krawchuk, M. A., Kull, C. A., Marston, J. B., Moritz, M. A., Prentice, I. C., Roos, C. I., Scott, A. C., Swetnam, T. W., van der Werf, G. R., and Pyne, S. J.: Fire in the Earth system, Science, 324, 481-4, doi:10.1126/science.1163886, 2009.

Briggs, G.: Plume Rise Predictions, Lectures on air pollution and environmental impact analysis, 59-111, 1975.

Crutzen, P. and Andreae, M.: Biomass burning in the tropics: impact on atmospheric chemistry and biogeochemical cycles, Science, 250, 1669-1678, doi:10.1126/science.250.4988.1669, 1990.

Damoah, R., Spichtinger, N., Servranckx, R., Fromm, M., Eloranta, E. W., Razenkov, I. A., James, P., Shulski, M., Forster, C., and Stohl, A.: A case study of pyro-convection using transport model and remote sensing data, Atmos. Chem. Phys., 6, 173185, doi:10.5194/acp-6-173-2006, 2006.

Dee, D. P., Uppala, S. M., Simmons, A. J., Berrisford, P., Poli, P., Kobayashi, S., Andrae, U., Balmaseda, M. A., Balsamo, G., Bauer, P., Bechtold, P., Beljaars, A. C. M., van de Berg, L., Bidlot, J., Bormann, N., Delsol, C., Dragani, R., Fuentes, M., Geer, A. J., Haimberger, L., Healy, S. B., Hersbach, H., Hólm, E. V., Isaksen, L., Kållberg, P., Köhler, M., Matricardi, M., McNally, A. P., Monge-Sanz, B. M., Morcrette, J.-J., Park, B.-K., Peubey, C., de Rosnay, P., Tavolato, C., Thépaut, J.-N., and Vitart, F.: The ERA-interim reanalysis: configuration and performance of the data assimilation system, Q. J. Roy. Meteorol. Soc., 137, 553-597, doi:10.1002/qj.828, 2011.

de Groot, W. J., Flannigan, M. D., and Cantin, A. S.: Climate change impacts on future boreal fire regimes, Forest Ecol. Manag., 294, 35-44, doi:10.1016/j.foreco.2012.09.027, 2013.

Dentener, F., Kinne, S., Bond, T., Boucher, O., Cofala, J., Generoso, S., Ginoux, P., Gong, S., Hoelzemann, J. J., Ito, A., Marelli, L., Penner, J. E., Putaud, J.-P., Textor, C., Schulz, M., van der Werf, G. R., and Wilson, J.: Emissions of primary aerosol and precursor gases in the years 2000 and 1750 prescribed data-sets for AeroCom, Atmos. Chem. Phys., 6, 4321-4344, doi:10.5194/acp-64321-2006, 2006.

Diner, D. J., Nelson, D. L., Chen, Y., Kahn, R. A., Logan, J., Leung, F.-Y., and Val Martin, M.: Quantitative studies of wildfire smoke injection heights with the Terra Multiangle Imaging SpectroRadiometer, Proc. SPIE, 7089, 708908, doi:10.1117/12.795215, 2008.

Dirksen, R. J., Folkert Boersma, K., de Laat, J., Stammes, P., van der Werf, G. R., Val Martin, M., and Kelder, H. M.: An aerosol boomerang: rapid around-the-world transport of smoke from the December 2006 Australian forest fires observed from space, J. Geophys. Res., 114, D21201, doi:10.1029/2009JD012360, 2009.

Freitas, S. R., Longo, K. M., Chatfield, R., Latham, D., Silva Dias, M. A. F., Andreae, M. O., Prins, E., Santos, J. C., Gielow, R., and Carvalho Jr., J. A.: Including the sub-grid scale plume rise of vegetation fires in low resolution atmospheric transport models, At- 
mos. Chem. Phys., 7, 3385-3398, doi:10.5194/acp-7-3385-2007, 2007.

Freitas, S. R., Longo, K. M., Trentmann, J., and Latham, D.: Technical Note: Sensitivity of 1-D smoke plume rise models to the inclusion of environmental wind drag, Atmos. Chem. Phys., 10, 585-594, doi:10.5194/acp-10-585-2010, 2010.

Fromm, M., Tupper, A., Rosenfeld, D., Servranckx, R., and McRae, R.: Violent pyro-convective storm devastates Australia's capital and pollutes the stratosphere, Geophys. Res. Lett., 33, L05815, doi:10.1029/2005GL025161, 2006.

Fromm, M., Torres, O., Diner, D., Lindsey, D., Vant Hull, B., Servranckx, R., Shettle, E. P., and Li, Z.: Stratospheric impact of the Chisholm pyrocumulonimbus eruption: 1. Earthviewing satellite perspective, J. Geophys. Res., 113, D08202, doi:10.1029/2007JD009153, 2008.

Giorgetta, M. A., Jungclaus, J., Reick, C. H., Legutke, S., Bader, J., Böttinger, M., Brovkin, V., Crueger, T., Esch, M., Fieg, K., Glushak, K., Gayler, V., Haak, H., Hollweg, H.-D., Ilyina, T., Kinne, S., Kornblueh, L., Matei, D., Mauritsen, T., Mikolajewicz, U., Mueller, W., Notz, D., Pithan, F., Raddatz, T., Rast, S., Redler, R., Roeckner, E., Schmidt, H., Schnur, R., Segschneider, J., Six, K. D., Stockhause, M., Timmreck, C., Wegner, J., Widmann, H., Wieners, K.-H., Claussen, M., Marotzke, J., and Stevens, B.: Climate and carbon cycle changes from 1850 to 2100 in MPI-ESM simulations for the Coupled Model Intercomparison Project phase 5, J. Adv. Model. Earth Syst., 5, 572-597, doi:10.1002/jame.20038, 2013.

Gonzi, S. and Palmer, P. I.: Vertical transport of surface fire emissions observed from space, J. Geophys. Res., 115, D02306, doi:10.1029/2009JD012053, 2010.

Gonzi, S., Palmer, P. I., Paugam, R., Wooster, M., and Deeter, M. N.: Quantifying pyroconvective injection heights using observations of fire energy: sensitivity of spaceborne observations of carbon monoxide, Atmos. Chem. Phys., 15, 4339-4355, doi:10.5194/acp-15-4339-2015, 2015.

Goodrick, S., Achtemeier, G., and Larkin, N.: Modelling smoke transport from wildland fires: a review, Int. J. Wildland Fire, 22, 83-94, doi:10.1071/WF11116, 2012.

Heald, C. L., Ridley, D. A., Kroll, J. H., Barrett, S. R. H., CadyPereira, K. E., Alvarado, M. J., and Holmes, C. D.: Contrasting the direct radiative effect and direct radiative forcing of aerosols, Atmos. Chem. Phys., 14, 5513-5527, doi:10.5194/acp-14-55132014, 2014.

Heikes, K. E. and Angeles, L.: Numerical simulation of small area fires, Atmos. Environ. A-Gen., 24, 297-307, doi:10.1016/09601686(90)90110-9, 1990.

Heilman, W. E., Liu, Y., Urbanski, S., Kovalev, V., and Mickler, R.: Wildland fire emissions, carbon, and climate: plume rise, atmospheric transport, and chemistry processes, Forest Ecol. Manag., 317, 80-96, doi:10.1016/j.foreco.2013.02.001, 2013.

Henderson, S. B., Ichoku, C., Burkholder, B. J., Brauer, M., and Jackson, P. L.: The validity and utility of MODIS data for simple estimation of area burned and aerosols emitted by wildfire events, Int. J. Wildland Fire, 19, 844, doi:10.1071/WF09027, 2010.

Hodzic, A., Madronich, S., Bohn, B., Massie, S., Menut, L., and Wiedinmyer, C.: Wildfire particulate matter in Europe during summer 2003: meso-scale modeling of smoke emissions, transport and radiative effects, Atmos. Chem. Phys., 7, 4043-4064, doi:10.5194/acp-7-4043-2007, 2007.
Hyer, E. J., Allen, D. J., and Kasischke, E. S.: Examining injection properties of boreal forest fires using surface and satellite measurements of CO transport, J. Geophys. Res., 112, D18307, doi:10.1029/2006JD008232, 2007.

Ichoku, C., Kahn, R., and Chin, M.: Satellite contributions to the quantitative characterization of biomass burning for climate modeling, Atmos. Res., 111, 1-28, doi:10.1016/j.atmosres.2012.03.007, 2012.

Jian, Y. and Fu, T.-M.: Injection heights of springtime biomassburning plumes over peninsular Southeast Asia and their impacts on long-range pollutant transport, Atmos. Chem. Phys., 14, 3977-3989, doi:10.5194/acp-14-3977-2014, 2014.

Kahn, R. A., Chen, Y., Nelson, D. L., Leung, F.-Y., Li, Q., Diner, D. J., and Logan, J. A.: Wildfire smoke injection heights: two perspectives from space, Geophys. Res. Lett., 35, 18-21, doi:10.1029/2007GL032165, 2008.

Kaiser, J. W., Heil, A., Andreae, M. O., Benedetti, A., Chubarova, N., Jones, L., Morcrette, J.-J., Razinger, M., Schultz, M. G., Suttie, M., and van der Werf, G. R.: Biomass burning emissions estimated with a global fire assimilation system based on observed fire radiative power, Biogeosciences, 9, 527-554, doi:10.5194/bg-9-527-2012, 2012.

Keywood, M., Kanakidou, M., Stohl, A., Dentener, F., Grassi, G., Meyer, C. P., Torseth, K., Edwards, D., Thompson, A. M., Lohmann, U., and Burrows, J.: Fire in the Air Biomass burning impacts in a changing climate, Crit. Rev. Env. Sci. Tec., 43, 40-83, doi:10.1080/10643389.2011.604248, 2013.

Kipling, Z., Stier, P., Schwarz, J. P., Perring, A. E., Spackman, J. R., Mann, G. W., Johnson, C. E., and Telford, P. J.: Constraints on aerosol processes in climate models from vertically-resolved aircraft observations of black carbon, Atmos. Chem. Phys., 13, 5969-5986, doi:10.5194/acp-13-5969-2013, 2013.

Kloster, S., Mahowald, N. M., Randerson, J. T., and Lawrence, P. J.: The impacts of climate, land use, and demography on fires during the 21 st century simulated by CLM-CN, Biogeosciences, 9, 509-525, doi:10.5194/bg-9-509-2012, 2012.

Konovalov, I. B., Berezin, E. V., Ciais, P., Broquet, G., Beekmann, M., Hadji-Lazaro, J., Clerbaux, C., Andreae, M. O., Kaiser, J. W., and Schulze, E.-D.: Constraining $\mathrm{CO}_{2}$ emissions from open biomass burning by satellite observations of co-emitted species: a method and its application to wildfires in Siberia, Atmos. Chem. Phys., 14, 10383-10410, doi:10.5194/acp-14-10383-2014, 2014.

Kukkonen, J., Nikmo, J., Sofiev, M., Riikonen, K., Petäjä, T., Virkkula, A., Levula, J., Schobesberger, S., and Webber, D. M.: Applicability of an integrated plume rise model for the dispersion from wild-land fires, Geosci. Model Dev., 7, 2663-2681, doi:10.5194/gmd-7-2663-2014, 2014.

Lasslop, G., Thonicke, K., and Kloster, S.: SPITFIRE within the MPI Earth system model: model development and evaluation, J. Adv. Model. Earth Syst., 6, 740-755, doi:10.1002/2013MS000284, 2014.

Lavoué, D., Liousse, C., Cachier, H., Stocks, B. J., and Goldammer, J. G.: Modeling of carbonaceous particles emitted by boreal and temperate wildfires at northern latitudes, J. Geophys. Res., 105, 26871-26890, doi:10.1029/2000JD900180, 2000.

Leung, F.-Y. T., Logan, J. A., Park, R., Hyer, E., Kasischke, E., Streets, D., and Yurganov, L.: Impacts of enhanced biomass burning in the boreal forests in 1998 on tropospheric 
chemistry and the sensitivity of model results to the injection height of emissions, J. Geophys. Res., 112, D10313, doi:10.1029/2006JD008132, 2007.

Liu, Y., Achtemeier, G. L., Goodrick, S. L., and Jackson, W. A.: Important parameters for smoke plume rise simulation with Daysmoke, Atmos. Pollut. Res., 1, 250-259, doi:10.5094/APR.2010.032, 2010.

Liu, Y., Goodrick, S. L., Achtemeier, G. L., Forbus, K., and Combs, D.: Smoke plume height measurement of prescribed burns in the south-eastern United States, Int. J. Wildland Fire, 22, 130-147, doi:10.1071/WF11072, 2013.

Luderer, G., Trentmann, J., Winterrath, T., Textor, C., Herzog, M., Graf, H. F., and Andreae, M. O.: Modeling of biomass smoke injection into the lower stratosphere by a large forest fire (Part II): sensitivity studies, Atmos. Chem. Phys., 6, 5261-5277, doi:10.5194/acp-6-5261-2006, 2006.

Mazzoni, D., Logan, J. A., Diner, D., Kahn, R., Tong, L., and $\mathrm{Li}, \mathrm{Q}$.: A data-mining approach to associating MISR smoke plume heights with MODIS fire measurements, Remote Sens. Environ., 107, 138-148, doi:10.1016/j.rse.2006.08.014, 2007.

Melnikov, V. M., Zrnic, D. S., Rabin, R. M., and Zhang, P.: Radar polarimetric signatures of fire plumes in Oklahoma, Geophys. Res. Lett., 35, L14815, doi:10.1029/2008GL034311, 2008.

Mims, S., Kahn, R., Moroney, C., Gaitley, B., Nelson, D., and Garay, M.: MISR Stereo Heights of Grassland Fire Smoke Plumes in Australia, IEEE T. Geosci. Remote, 48, 25-35, doi:10.1109/TGRS.2009.2027114, 2010.

Nelson, D. L., Chen, Y., Kahn, R. A., Diner, D. J., and Mazzoni, D.: Example applications of the MISR INteractive eXplorer (MINX) software tool to wildfire smoke plume analyses, Proc. SPIE, 7089, 708909-708909-11, doi:10.1117/12.795087, 2008.

Nelson, D., Garay, M., Kahn, R., and Dunst, B.: Stereoscopic Height and Wind Retrievals for Aerosol Plumes with the MISR INteractive eXplorer (MINX), Remote Sens., 5, 4593-4628, doi:10.3390/rs5094593, 2013.

Peterson, D. and Wang, J.: A sub-pixel-based calculation of fire radiative power from MODIS observations: 2. Sensitivity analysis and potential fire weather application, Remote Sens. Environ., 129, 231-249, doi:10.1016/j.rse.2012.10.020, 2013.

Peterson, D., Hyer, E., and Wang, J.: Quantifying the potential for high-altitude smoke injection in the North American boreal forest using the standard MODIS fire products and subpixelbased methods, J. Geophys. Res.-Atmos., 119, 3401-3419, doi:10.1002/2013JD021067, 2014.

Rio, C., Hourdin, F., and Chédin, A.: Numerical simulation of tropospheric injection of biomass burning products by pyro-thermal plumes, Atmos. Chem. Phys., 10, 3463-3478, doi:10.5194/acp10-3463-2010, 2010.

Rosário, N. E., Longo, K. M., Freitas, S. R., Yamasoe, M. A., and Fonseca, R. M.: Modeling the South American regional smoke plume: aerosol optical depth variability and surface shortwave flux perturbation, Atmos. Chem. Phys., 13, 2923-2938, doi:10.5194/acp-13-2923-2013, 2013.

Schroeder, W., Ellicott, E., Ichoku, C., Ellison, L., Dickinson, M. B., Ottmar, R. D., Clements, C., Hall, D., Ambrosia, V., and Kremens, R.: Integrated active fire retrievals and biomass burning emissions using complementary near-coincident ground, airborne and spaceborne sensor data, Remote Sens. Environ., 140, 719-730, doi:10.1016/j.rse.2013.10.010, 2014.
Sessions, W. R., Fuelberg, H. E., Kahn, R. A., and Winker, D. M.: An investigation of methods for injecting emissions from boreal wildfires using WRF-Chem during ARCTAS, Atmos. Chem. Phys., 11, 5719-5744, doi:10.5194/acp-11-5719-2011, 2011.

Siddaway, J. M. and Petelina, S. V.: Transport and evolution of the 2009 Australian Black Saturday bushfire smoke in the lower stratosphere observed by OSIRIS on Odin, J. Geophys. Res., 116, 1-9, doi:10.1029/2010JD015162, 2011.

Sofiev, M., Ermakova, T., and Vankevich, R.: Evaluation of the smoke-injection height from wild-land fires using remote-sensing data, Atmos. Chem. Phys., 12, 1995-2006, doi:10.5194/acp-12-1995-2012, 2012.

Sofiev, M., Vankevich, R., Ermakova, T., and Hakkarainen, J.: Global mapping of maximum emission heights and resulting vertical profiles of wildfire emissions, Atmos. Chem. Phys., 13, 7039-7052, doi:10.5194/acp-13-7039-2013, 2013.

Stevens, B., Giorgetta, M., Esch, M., Mauritsen, T., Crueger, T., Rast, S., Salzmann, M., Schmidt, H., Bader, J., Block, K., Brokopf, R., Fast, I., Kinne, S., Kornblueh, L., Lohmann, U., Pincus, R., Reichler, T., and Roeckner, E.: Atmospheric component of the MPI-M Earth system model: ECHAM6, J. Adv. Model. Earth Syst., 5, 146-172, doi:10.1002/jame.20015, 2013.

Stier, P., Feichter, J., Kinne, S., Kloster, S., Vignati, E., Wilson, J., Ganzeveld, L., Tegen, I., Werner, M., Balkanski, Y., Schulz, M., Boucher, O., Minikin, A., and Petzold, A.: The aerosol-climate model ECHAM5-HAM, Atmos. Chem. Phys., 5, 1125-1156, doi:10.5194/acp-5-1125-2005, 2005.

Stocks, B., Fosberg, M., and Lynham, T.: Climate change and forest fire potential in Russian and Canadian boreal forests, Clim. Change, 38, 1-13, doi:10.1023/A:1005306001055, 1998.

Strada, S., Freitas, S. R., Mari, C., Longo, K. M., and Paugam, R.: One-dimensional simulation of fire injection heights in contrasted meteorological scenarios with PRM and MesoNH models, Geosci. Model Dev. Discuss., 6, 721-790, doi:10.5194/gmdd-6-721-2013, 2013.

Tosca, M. G., Randerson, J. T., Zender, C. S., Nelson, D. L., Diner, D. J., and Logan, J. A.: Dynamics of fire plumes and smoke clouds associated with peat and deforestation fires in Indonesia, J. Geophys. Res., 116, 1-14, doi:10.1029/2010JD015148, 2011.

Tosca, M. G., Randerson, J. T., and Zender, C. S.: Global impact of smoke aerosols from landscape fires on climate and the Hadley circulation, Atmos. Chem. Phys., 13, 5227-5241, doi:10.5194/acp-13-5227-2013, 2013.

Trentmann, J., Luderer, G., Winterrath, T., Fromm, M. D., Servranckx, R., Textor, C., Herzog, M., Graf, H.-F., and Andreae, M. O.: Modeling of biomass smoke injection into the lower stratosphere by a large forest fire (Part I): reference simulation, Atmos. Chem. Phys., 6, 5247-5260, doi:10.5194/acp-65247-2006, 2006.

Twomey, S.: The influence of pollution on the shortwave albedo of clouds, J. Atmos. Sci., 34, 1149-1152, doi:10.1175/15200469(1977)034<1149:TIOPOT>2.0.CO;2, 1977.

Val Martin, M., Logan, J. A., Kahn, R. A., Leung, F.-Y., Nelson, D. L., and Diner, D. J.: Smoke injection heights from fires in North America: analysis of 5 years of satellite observations, Atmos. Chem. Phys., 10, 1491-1510, doi:10.5194/acp-10-14912010, 2010. 
Val Martin, M., Kahn, R. A., Logan, J. A., Paugam, R., Wooster, M., and Ichoku, C.: Space-based observational constraints for 1-D fire smoke plume-rise models, J. Geophys. Res., 117, D22204, doi:10.1029/2012JD018370, 2012.

Veira, A., Kloster, S., Schutgens, N. A. J., and Kaiser, J. W.: Fire emission heights in the climate system - Part 2: Impact on transport, black carbon concentrations and radiation, Atmos. Chem. Phys., 15, Atmos. Chem. Phys., 15, 7173-7193, doi:10.5194/acp-15-7173-2015, 2015.

Ward, D. S., Kloster, S., Mahowald, N. M., Rogers, B. M., Randerson, J. T., and Hess, P. G.: The changing radiative forcing of fires: global model estimates for past, present and future, Atmos. Chem. Phys., 12, 10857-10886, doi:10.5194/acp12-10857-2012, 2012.
Zhang, K., O’Donnell, D., Kazil, J., Stier, P., Kinne, S., Lohmann, U., Ferrachat, S., Croft, B., Quaas, J., Wan, H., Rast, S., and Feichter, J.: The global aerosol-climate model ECHAM-HAM, version 2: sensitivity to improvements in process representations, Atmos. Chem. Phys., 12, 8911-8949, doi:10.5194/acp-12-89112012, 2012a.

Zhang, X., Kondragunta, S., Ram, J., Schmidt, C., and Huang, H.C.: Near-real-time global biomass burning emissions product from geostationary satellite constellation, J. Geophys. Res., 117, D14201, doi:10.1029/2012JD017459, 2012b. 